Eugenie A. Samier, Philosophical and Historical Origins and Genesis of Islamic Global Governance

\title{
Introduction
}

Most of the literature on global governance emphasises the roles of Western nations, transnational corporations that originate in the West, and international organisations like the WTO and OECD which also exhibit a Western neoliberal bias and domination over other parts of the world (Michie, 2011). Even though other regions are receiving recent attention and have formed transnational organisations that represent their interests and provide some opportunities for participation in global governance, the perspectives of non-Western countries in interpreting global governance does not leave room for conceptions arising from other cultures. One of these regions is the Muslim world, which ironically was one of the main foundational sources for modern disciplines in the West during the Renaissance and which continued to shape ideas during the Enlightenment (Akasoy \& Giglioni, 2013). It is from this intellectual heritage that concepts of global governance were forming in modern history, for example, through influence on Kant's (1795/2006) essay “Toward Perpetual Peace.”

However, identifying Islamic principles of governance in practice has been complicated by a political history that dissociated many Muslim states from traditional foundations, including the European colonisation of the Middle East, the decline of the Ottoman Empire, and later national independences and political instabilities. Governance structures and practices in Muslim countries are shaped by a confluence of many factors. Most are in a postcolonial condition 
whose national structures and systems of governance inherited colonial forms in their political systems, legal frameworks and institutional arrangements that emerged from complex interplays between colonial powers and the indigenous societies they administered producing a broad range of national regimes across the colonised world (Maussen \& Bader, 2011).

The governance field is also complicated by negative stereotypes of Islam, critiqued through the "Orientalism" stereotype discussed by Said as early as 1978 and is evident in the highly polarised "clash of civilisations" theory propounded by authors like Huntington (1997). The current political climate is not particularly conducive to considering or accepting Islamic conceptions of global governance as complementary or contributory to a discussion of how they can complement current global governance. The negative politics of scholarship in Islamic studies consists in a number of assumptions about Western theories and models and in those about the Islamic world that are presented as opposed. This includes a secularised Western social sciences (Fox, 2006; Hirschkind, 2011; Volpi, 2011), overgeneralisations, misrepresentations, negative stereotypes, and demonizations (Cole, 2009; Nader, 2013; Shaheed, 1999) of Muslim societies, and a confusion of Islam with militant or fundamentalist Islamism (Badran, 2001) that ends up excluding Islamic schools of thought. While Fukuyama and Huntington present the West as having the only viable paradigm for development and democracy (see Mahdavi \& Knight, 2012), they are not alone in mistaken assumptions that underlie much of the discussion in global governance.

However, Islamic conceptions of global governance are distinct but not wholly different from many Western conceptions. Among an increasing number of scholars, Bilgin (2009) has 
criticised the empirical and ideological problem of assuming a "West versus the rest" position since it is not historically accurate, ignoring the centuries of intellectual transmission from one region to another, it has acquired a dominant-passive character by having been used to justify colonisation, and it polarises knowledge and values that are not that different from each other. What is produced are assumptions that the "rest's"" contribution to knowledge is not acknowledged, assigning rationalism to the West and non-rational or spiritual character to the rest. The most common, according to Grugel and Piper $(2007$, p. 3$)$ is a pro-Western "system based on pluralism and liberal inclusion" aimed at embedding "Western authority" which underpins organizations like the Commission on Global Governance (see also Sabet, 2008; Sinclair, 2012) and which also inform security studies, argued by Barkawi and Laffey (2006) to be dominated by Western powers in international organizations like the United Nations, and reflect a sequence of "civilising missions" including "white man's burden," the "humanitarian internvention of the 1990s, or the post-9/11 invasions of Afghanistand and Iraq" (p. 351). It is for this reason that a great lacuna exists in literature on global governance representing actual global thoughts and contributions to the field, the case of silence on Muslim thought of central concern in this chapter.

The approach one takes to global governance affects what can be included in the discussion, and how it is conceptualised. For example, realist and structural-functionalist approaches focus on existing structures tend to exclude considerations of morality and religious systems. This chapter takes a critical constructivist approach in which global governance takes places in an "intersubjective context of shared knowledge about the world" consisting of "identities, interests, 
and behaviour" producing social institutions (Hoffmann, 2005, p. 111). This dynamic can take many forms through rules, institutions, norms and world orders, in effect a decentring of definitions and structures of global governance from a Western location to a more diffuse international network of organisations produced through mutual constitution. Most important for an exploration of Islamic global governance is that social constructivism examines ideas, beliefs, norms and discourses that encompass the participation of all global regions in contrast to a neoliberal view that focusses on regulative rules and structures that are heavily dominated by several Western powers (Hoffmann, 2005) yielding multi-centric theories like that of Rosenau (1990). This approach allows for a broader exploration of ways in which Islamic governance practices can be used internationally, for example, in the Islamic arbitration and dispute resolution system that is recognised in many Western states and the establishment of the International Islamic Centre for Reconciliation and Arbitration.

Governance and a global perspective have been fundamental principles in Islam since its inception, and continue to play a critical role in the political and intellectual development of Muslim states up to the modern period. In exploring the potential for Islamic involvement in global governance currently, a number of questions come to mind including: What is global governance in Islam? How compatible is Islamic governance at the global level with other global governance systems and approaches? A question Sachedina (2006) poses is: "Are there resources within the classically inherited tradition that can be tapped for the creation of a nationstate that is also a member of the international public order?" (p. 5). The purpose of this chapter is to answer these questions in tracing the philosophical origins and genesis of the central original concepts of global governance in Islam, including its historical development through the 
preceding conceptions in the region, the Qur'an and the governance practices of the Prophet Muhammad, and the caliphs who immediately succeeded him, generally considered to have constructed the most authentic Islamic model of leadership and government, how governance was conceptualised in the Islamic intellectual tradition, followed by a discussion of the potential for Islamic contributions to contemporary global governance.

\section{The History of the Concept}

One of the arguments for a consideration of modern Islamic global governance is that it did not arise without historical precedents. Conceptions and practices of global governance developed in ancient societies reflecting the establishment of both city states and empires and their networks that composed the region and their need to regulate trade and migrations (Cline, 2014; Edwards, Gadd \& Hammond, 1971). Contrary to much of the recent literature dating global governance to 1989 , the historical record goes back much further. Globalisation took militarised forms, as in Alexander the Great's expansion of empire across three continents, economic forms in the spice trade and silk road, environmental globalism of biological substances, and the social and cultural globalism of ideas ranging from religions, through intellectual traditions to modes of consciousness and attitudes that affect culture and identity (Keohane, 2002).

Murphy (2014) has traced this history through a number of "epochs" of global governance. The first is that of a system of rulers in Neolithic East Asia, South Asia, and West (including the Fertile Crescent and Mediterranean) who maintained a pursuit of "universal empire" to fend off nomadic raiders from the Eurasian steppes, followed by an epoch of continuous linked trading 
routes of Eastern, Southern and Western regions from the $12^{\text {th }}$ to the $8^{\text {th }}$ centuries BCE. It is this latter governance system that Murphy argues provided the foundation for the later Islamic trading system that extended to China in the third epoch. It is the third epoch in the medieval world whose technology and organisational knowledge contributed to the fourth epoch of global governance of $19^{\text {th }}$ century European systems of overseas empires and industrial competitiveness.

Following these, and in part building upon them, is the current global governance epoch characterised by international development systems and a neoliberal perspective. While all previous epochs had interests, ideas and institutions, the current one is distinguishable by tighter economic integration and a broad range of "coordination, harmonization, association, parallel national/action, functionalist cooperation, consociational federalism, regional autonomy" and decolonization and secessionist forms (Murphy, 2014, 218). Cline (2014) also demonstrates that previous globalised world systems existed in the past, investigating in detail that of the late Bronze Age, circa 1200 BCE consisting of empires from North Africa, the Middle East, the Mediterranean, and West Asia in which multiple civilizations were regularly interacting economically and were partially dependent on each other producing a global culture. Conceptions of global governance are also part of the history of political studies. What seems to be different now with globalization are the high levels of cross-border migrations, the rapidly increasing number of international organisations, and "the rapidity of its spread and the intensity of its interactions and their compression in real time" (Weiss, 2013, pp. 54-55), although connectivity is relative - as Goldin (2013) argues, for impoverished and developing nations, as 
well as those on the 'periphery' of major Western powers, a lack of connectivity is still a problem.

\section{The Islamic Conception of Global Governance}

The Islamic conception of governance, although distinctively different from current Western definitions of good governance associated with democracy, civil rights, transparency, the rule of law and effective public services (e.g., Weiss, 2005), does share a number of foundational concepts, although expressed over time in a number of different societal and political forms. Islamic governance is not only a complex concept, but also refers to a number of normative topics in the establishment of government and leadership. This section examines the core texts and leaders of the early Islamic community who defined, described and practiced governance. The most important sources for conceptions of global and good governance are the ideal and fundamental principles in the Qur'an, the Hadith (teaching of the Prophet Muhammad) and Sunnah (the actions of the Prophet). During the period of Muhammad (in Medina 622-632) and the Rashidun, or Rightly Guided Caliphs who immediately succeeded him, those fundamental principles relating to a polity included the development of institutions of governance such as a judicial system, administrative system, economic system and foreign affairs as well as what became social and cultural institutions. This period also represents for most Muslims the ideal period of governance before other interests and practices influenced political systems that arose later. This includes Abu Bakr (632-634), Umar (634-644), Uthman (644-656) and Ali (656661), particularly Abu Bakr and Umar, generally regarded as the closest to the principles because of personal and historical closeness to the Prophet. 
There are two Arabic terms in the literature that have been identified as close to the English term "governance." The first is al-hakimiya, which Iqbal and Lewis (2009) describe as going beyond a procedural definition of governance to include a higher moral social order and for Muslims a submission to the authority of Allah, in contrast to Western secular conceptions that are functionalist in nature. Its three main dimensions are moral values, humanity as a brotherhood, and socio-economic justice, intended to be carried out with fairness, equality and honesty. Another term, siyasa, is defined by Crone (2004) to take three forms: governance of oneself through ethics, governance of the household, and governance of the polity. It also refers more diversely to the systems of governance that characterise the Caliphates following the early period especially the Abbasid Caliphate (750-1258) during which time many structures of government were developed. Possibly the most complex empirically are the governance traditions of contemporary Muslim states with different histories, conditions, cultures and societal configurations that have produced a great diversity in governance practices. Principally, though, governance in Islam refers to how leaders are chosen and the qualities of good leadership that lead to good governance.

Islam operates on the level of humankind, so part of its focus is on the global rather than state level where differences should be transcended, aimed at betterment of individuals and humanity in general (Oliver-Dee, 2009). Sachedina (2006) defines the Islamic tradition as "a public project founded upon the principle of coexistence recognizing self-governing communities that 
are free to run their internal affairs under a comprehensive religious and social political system" (p. 6) and intended to be principles with universal application that regulate Muslim societies and their relationships with the non-Islamic world that advocate the community of interests among nations (Baderin, 2000). While this last point is an issue of debate in Islamic discourse, there are many like Baderin (2000) who argue that participation in a modern international order does not demand a departure from the norms of Islamic principles aimed at cooperation, friendly international relations and a peaceful co-existence. He further emphasises the basis of "sincerity, equity, righteousness and piety" that are encouraged for which the political practice of the Prophet Muhammad is a precedent and is embodied in the "Constitution of Medina" (p. 59) including maintaining peaceful alliances with surrounding communities. Demirei (2013) argues that the foundational character of Islam through the Prophet Muhammad and especially his Constitution of Medina serves as models for pluralism and coexistence. Part of this tradition is a restriction on any form of reciprocity that violates fundamental human rights and religious principle, even in the case of violations by an enemy. The Constitution of Medina set into the foundational governance system principles of peoples of different religions living together peacefully as a confederation where non-Muslims had the right to participation and in governance over their own communities' affairs in 'an atmosphere of free speech and dialogue by mutual consent' (p. 8) that required a pluralistic system of justice. Articles in the constitution include those that prohibited oppression of any group and that appointment to government posts be based on qualifications not religious background, a feature of later Islamic empires such as the Umayyad (661-750) and Abbasid (750-1258) that was very common in the appointment of many senior officials who were expertly qualified and non-Muslim. 
These practices demonstrate that maintaining an Islamic identity did not isolate it from constructive relations in it socio-political environment characterised by humanitarianism, cooperation in pursuit of international justice, peace, security and welfare of all peoples, principles generally carried forward into the many later empires and in their relations with nonIslamic societies often taking the form of peace treaties, despite periods of war, internal conflict and conquest as well as a high multiculturation of the empires as they absorbed other empires and city states into their territories. Islamic empires were relatively successful in constructing governance, administration and justice systems that operated on these principles producing an Islamic development of administrative systems and practices that also became one of the sources of administrative development in Europe (Bennison, 2009; Johns, 2002) These principles Baderin (2000) compares with UN articles relating to international peace and cooperation and in the establishing charter of the Organization of Islamic Cooperation in 1969, supplemented with a declaration on dialogue internationally, one means through which Islamic ideals of justice and equity play a role in global governance, although to date its effect is mixed (covered in more detail in the Tok chapter).

Equally important is the Qur'an's call to humanity to use reason in moral decision-making in the pursuit of justice as a universal human endeavour that Sachedina (2006) argues can serve as a source of unity across religious differences in a tradition that recognised religious pluralism, carried out with a spirit of accommodation and tolerance. The role of governance in the Qur'an is to "control 'discord on earth"" and protect the well-being of the community. The classical Islamic worldview is concerned with both Islamic societies and an external view that Sabet (2008) argues produces an Islamic law of nations consisting of foundational principles for 
alliances, treaties, trade relations, etc. The primary values of betterment of humanity and maintaining a social order I would argue here applies equally internally to a Muslim society and externally to its global neighbours. The causal link between legitimate political authority and moral excellence is exemplified in the Prophet Muhammad including personal characteristics of 'veracity/honesty, generosity, courage, and possession of knowledge' in the last consisting of both mundane and religious knowledge (Afsaruddin, 2010, p. 187) which can also serve the main principles of global governance for human rights, peaceful co-existence, societal development, and a just economy internationally.

One of the most important aspects of governance - the selection of political leaders - has had a complex and variable history in the Rashidun period from Umar's appointment of a group of six prominent men to form a council to elect a new ruler, regarded by many as a precursor to democracy (Afsaruddin, 2007), to Uthman's more centralised conception of governance in his sole selection of provincial governors, although they were allowed considerable autonomy (Kennedy, 2005). It was during this early period that the largest schism in Islam formed over the qualifications for succession: for Sunnis it is the legitimacy of the four Rashidun caliphs, Abu Bakr, Umar and Uthman followed by Ali; for the Shia, the blood relationship of Ali is the qualifying criterion with the other caliphs viewed as usurpers (Afsaruddin, 2010; Kennedy, 2005). The first exemplar after the Prophet Muhammad of good governance is Umar ibn alKhattab, who began the development of practice based on these principles, for example, defining a number of conditions that should govern the selection and appointment of civil servants such as being pious, capable and trustworthy, a testing period of two or three years in which behaviour and competency can be determined, and high salaries and conditions of employment intended to 
curb malpractice and corruption (al-Qudsy \& ab Rahman, 2011). Two other characteristics evidenced in Umar's practice was in graciously receiving warranted correction and in extensively using shura, or consultation as well as a special office of the caliph that receives and investigates complaints and strategic planning for the economic system.

The Islamic theory of governance is grounded in a number of principles that derive from the early history, one of which is al-siasah al-shar'iyyah meaning the arrangement, management and political wisdom to achieve the fundamental aims of human benefit and protection, as well as to carry out good purposes (al-Qudsy \& ab Rahman, 2011) or the "common good” (Sachedina, 2006)). Drawing on a number of sources on Islamic governance, al-Qudsy and ab Rahman (2011) characterise Islamic governance as that which follows the core values and fundamental precepts of government: administration and constitutional law, the rights of the individual, the public interest and benefit. For Al Buraey (1985), the core concept is yudabbiru, meaning the order, planning, management and steering required for constructive economic practices and through the people, similar to that of modern democratic theory.

The term shari'ah has a range of meanings, and is a matter of some debate about various interpretations. Shari'ah refers to both a set of religious values constituting "the way," and principles of Islamic justice including civil transaction, the protection of life, protection of dignity or lineage, protection of intellect, protection of property and protection of al-din (religion) and is closely associated with fiqh, the corpus juris of the main legal schools (Kamali, 2008; al-Qudsy \& ab Rahman, 2011). As Hashem (2007) explains, the primary definition of shari'ah as a value orientation is often confused with a second definition referring to historical 
understanding, where the former is open to continuous reinterpretation as conditions change allowing for the stability of its unchanging fundamental values and principles and an adaptability it their application. There are many passages in the Qur'an and Sunnah describing governance, summarised by al-Qudsy and ab Rahman (2011) as focussing on serving the community, acting as guardian, and society requiring an ethical culture in order for governance to be enacted, and a set of moral values (Akhlaq) that individuals must live up to in order to participate in legitimate governance such as practicing ijtihad (legal reasoning based in normative texts and a rational process of interpretation): honesty and integrity, administration of justice, loyalty, personal responsibility, and cooperation. Principles of practice in achieving these are faith, accountability (in a non-neoliberal market-based sense), good moral values, mutual consultation and the prevention and forbidding of wrongdoing (al-Qudsy \& ab Rahman, 2011).

Al-shura also provides for other values associated with good governance: 'transparency, accountability, respect, empowerment, freedom of expression, dignity of the human individual and cooperation' (al-Qudsy \& ab Rahman, 2011, p. 621; Zein, al-Ahsan \& Zakaullah, 2008). These are accompanied by rida al awam (popular consent), ijtihad jama'i (collective deliberation), and mas'uliyah mama'iyyah (collective responsibility). The Sunnah also provides a rich source of governance-related principles in the Prophet Muhammad's practices, even before a battle calling together nearby Muslims for consultation and even though he did not agree with the majority position, he followed it (Sharfuddin, 1987). The Rashidun caliph Umar adopted the title Amir al-Mu'minin (Counseller/Leader of the faithful) indicating his position as a first among equals (Afsaruddin, 2007). He also adhered to consultation viewing it as a strengthening of decision-making beyond what one individual is capable of (Sharfuddin, 1987), although the 
actual mechanisms for this are not prescribed allowing for flexibility under different conditions. There are also requirements for the advice provided including sincerity and honesty exemplified in five rules described by Sharfuddin (1987, p. 231): it must be done in a non-accusing manner; one should not expect instant compliance; advise only on what one would follow oneself; it should be given at the right time and in the right manner; and exhibited through personal example.

Three other concepts are associated with the pursuit of good governance $a d l$, that is justice and equity, and ihsan, or benevolence, extended not only to Muslims but equally to non-believers with the objective of establishing a tolerant, just and equitable world order (Iqbal and Lewis, 2009). Related also is the principle of amanah in the Qur'an, the trust given to mankind to establish justice in society in relation to all others and the environment implying from the word's root to include peace, security and safety, for which people have a personal responsibility in creating a moral order in personal interaction and through socio-political institutions (Zein, alAhsan \& Zakaullah, 2008). As Zein, al-Ahsan and Zakaullah (2008) explain, amanah is understood to apply universally and applied through an absolute principle of equality and social harmony including that of Muslim-non-Muslim relations.

The main purpose of governance in an Islamic system is to ensure that the state institutions and those regulated in society are aimed at the Islamic values of bettering the individual in the ways prescribed, and in establishing a just, fair, and equitable society - living up to the ideals of Islam for society. These are identified by Hashem (2007) as the following: 
- Achieve justice in society

- Maintain the dignity of individuals, protect group freedom

- Ensure that individuals achieve a sustainable livelihood

- Encourage virtue, limit vice, and reject compulsion in religious matters

- Encourage aims are reached through consultation, participation, representation, accountability mechanisms and through legal conventions

In a system of thought in which Allah is the ultimate law-giver and government an ordained institution, it has an ideal character, much like that in idealist Western philosophy where the pure conceptions exist independent of earth-bound contingencies, and they remain, unchanged and a guide to choice and decision making, much as ethical principles are viewed by Plato (Behzadi, 1971), in the same way that Kantian principles are 'ideal' and not often perfected in reality, similar to other socio-political concepts in political systems like democracy that are ideal concepts that are imperfectly attained in practice.

\section{The Classical Intellectual Tradition}

This section examines the classical Islamic intellectual tradition, generally understood to be the Islamic mediaeval period from the early seventh century when the Qur'an was written (610-632) to $1400 \mathrm{CE}$ (Peters, 1994), which was heavily influenced by Aristotelian thought on conceptions of governance, the state, and society (Crone, 2004; Rosenthal, 1962) through its influence on a number of scholars during this period. This tradition includes many significant figures, like Ibn Khaldun, Ibn Sina, Ibn Rushd and Al-Ghazali (Adamson \& Taylor, 2005; Sharif, 1963), not only 
for the Islamic world, but whose works were also transmitted to Europe primarily through the Renaissance, including the influence of Islamic legal institutions on the rule of law in Europe (Al-Rodhan, 2012) and which heavily influenced the European Enlightenment which provided strong philosophical foundations for modern conceptions of governance and globalism (e.g., Kant's cosmopolitanism) (Al-Tamamy, 2014; Attar, 2007).

One of the most important is Ibn Khaldun (1332-1406) whose interdisciplinary writings addressed both ideas and practices in Muslim states and empires. Through a strongly sociological lens, he wrote extensively on political leadership and characteristics of the regimes they established (Sidani, 2008). A concept central to his studies is asabiya (group feeling, solidarity, loyalty, esprit de corps), one of the main aims of governance in the Islamic tradition, particularly in addressing conflict and wars but also in forming communal connections with other peoples predicated upon both the consent of followers and tolerance for others consisting of two capacities, mulk (political power, kingship) and wazi' (a constraining force) including religious principles that prevent absolutism and formalised in law intended to apply universally to achieve harmony (Black, 2011). This can be extended from how governance operates within a society to the relationships one has with other societies. Lacoste (1984) has investigated just such a use of Ibn Khaldun's work in analysing relationships in the Middle East region, but which here is argued to extend globally.

Ibn Sina (980-1037, known as Avicenna in the West) is another scholar who interpreted governance among many other political and social concepts, stressing the interdependence of people in a society and government required to maintain the observance of civil and religious 
law (Bowering, 2013). Ibn Taymiyya (1263-1328) also wrote extensively on legal implications for governance, promoting the Islamic legal reasoning practice of ijtihad in which one determines the consensus of followers on various issues and establishes a middle ground between reason and tradition and between violence and piety aimed at a regulative rather than military form of government (Bowering, 2013). One more who should be included in even this short survey of governance writings is al-Mawardi (972-1058), who concentrated on the diwan or bureaucratic system necessary to good governance grounded in 'rational rule' rather than personal decisions and nepotism - in other words emphasizing the rule of law and qualifications for office (Bowering, 2013) and using istislah, or reliance on reasoning and discretionary opinion, in both governance responsibilities of protecting religion and a 'proper administration of the world' (Afsaruddin, 2010, p. 193). These sources were accompanied in political terms by conceptions of universalism and religious pluralism (Boase, 2010; Hashmi, 2002; Tibi, 2008), as well as traditions of Islam advocating rational thinking and scientific and interpretive reasoning (Hourani, 1985) that is argued here allows for building common ground in a strong participation in and principles for global governance in the contemporary world.

Complementing the scholarly intellectual tradition is a practitioner intellectual tradition of caliphs and senior officials who wrote a variety of guiding documents for good governance for rulers and administrators referred to as the Mirror of Princes tradition, which proliferated particularly in the Abbasid Empire (Crone, 2004). While the scope of this chapter does not allow for a detailed discussion, some of the more famous should be noted including the Ordinances of Government (al-Ahkam as-Sultaniyyah) by Abu'l-Hasan al-Mawardi and The Book of Government or Rules for Kings (Siyar al-Mulūk or Siyāsat-nāma) by Nizām. al-Mulk which 
translated governance principles into practical applications, particularly in establishing and managing empire (Boroujerdi, 2013).

This tradition in the Islamic world is rich with commentary, guidelines and interpretive texts on good rulership and administration including the many ways and levels in which governance is carried out. While not necessarily always carried out in practice, these texts do demonstrate a continuity in Islamic conceptions, values and expectations of rulers who were expected to adhere to the highest principles since they were regarded as role models for the citizenry as well as practical guidance in ensuring that officials are not abusing their power, advice on the qualities of officials one should appoint, the application of justice, the protection and care of one's citizens and the management of taxes and building programs as well as the proper use of an intelligence service (Crone, 2004). In other words, this body of literature was preoccupied with the principles and practices of good governance, particularly in establishing its application to a much larger and multicultural polity with extensive political and trade relations across several continents during the caliphates, taking into consideration changing socio-political and economic traditions and the absorption of other empires.

Governance changed and developed with the expansion of empire and as influences from other empires and cultures came into effect. The three main challenges during this expansion were to determine how the vast areas were to be governed given the absorption of people's with different cultural and political traditions, how to distribute resources, and finally how to select caliphs and establish the powers they should have (Kennedy, 2005). While the Abbasid system of governance acquired a more oriental Persian character of despotism, it did maintain core Islamic 
values of equality, fraternity, social justice and toleration, providing equal opportunities for longstanding Muslims and new ones in economic, political and cultural spheres including a high number of non-Muslim and non-Arabs occupying administrative roles. While its central administration adopted the strong wazir office from the Sassanid Empire, it also allowed for a high degree of local self-governance with each town and village managing its own affairs providing that order was maintained and taxes were paid (Gillani \& Tahir, 2014).

\section{Governance in the Modern Period}

The literature on global governance has expanded considerably since the 1970s with the intensification of globalisation and international connectedness producing what Overbeek (2005) calls neo-liberal global governance, reflecting the economic imperatives of neoliberalism that includes expansions of "market" into previously non-market sectors, the growth of commodification, the incorporation of previously state enterprises, and the subordination of other spheres to the economic, producing the new global political economy. There are other definitions of global governance, from the normative definition of the Commission on Global Governance (1995) viewing it as a process through which various policy actors accommodate interests and pursue cooperative action, the liberal rights-based definition aimed at pursuing human rights of equality of the individual (Grugel \& Piper, 2007; Sinclair, 2012), critical perspectives that focus on power analyses (e.g., Barnett \& Duvall, 2005) to a Marxist analysis that focusses on class hegemony applied nationally and internationally (e.g., Overbeek, 2005). One of the most comprehensive of definitions is that by Weiss and Wilkinson (2015) explored in this section: "the sum of the informal and formal ideas, values, norms, procedures, and 
institutions that help all actors - states, IGOs, civil society, and TNCs - identify, understand, and address trans-boundary problems" (p. 52). However, most of the global governance literature makes no reference to Islamic sources and conceptions, particularly the many aspects of global governance that are consistent with recent principles of stewardship, peaceful coexistence and aide to developing countries.

The concept of "good governance" in the contemporary period first appeared as a set of policies in the 1989 World Bank report "Sub-Saharan Africa: From Crisis to Sustainable Growth" is a neoliberal one including a reduction of state intervention in the economy, reduced public sectors, free markets, efficiency, integration into the world economy and other features of an economic liberalization (Najem, 2003; see also chapter by Pal). This initial conception included more indigenous and culturally sensitive argument for governance, although it was still neoliberal in its conception and in practice has resulted in "a wholesale endorsement of Western ideals, practices and institutions" (p. 3). However, the concept expanded subsequently to also include political reforms that are democratic, the promotion of civil society, human right, and the safeguarding of education, and health and the environment - in fact a large expansion that is not always clear in its use (Najem, 2003). There is also the emergence of what Jreisat (2011) calls 'new governance' examining the degree to which concepts of globalisation can travel across political systems, and which provides an opening conceptually to bring Islamic conceptions into play.

"Global governance" is a multidimensional and multi-level concept consisting of a set of actors, including the following: nation states; supra-national inter-governmental organisations like the 
UN, the EU, the GCC, and the Organisation of American States, ASEAN, COMESA, OPEC, League of Arabs States and the Organisation of Islamic Cooperation; transnational and multinational corporations; NGOs including professional associations like Médecins sans Frontières; citizens' movements, think tanks, private military forces, international treaty law from which arms control agreements, intellectual property laws, the law of the sea and environmental treaties originate (Grugel \& Piper, 2007; Karns, Mingst \& Stiles, 2015; Sinclair, 2012). It also includes networks among state actors both across borders and between state agencies and supra-national organisations like the European Court of Justice, corporate bodies, NGOs and individuals operating on an elite level (Slaughter, 2004; Weiss, 2013). The expansion of global governance actors through many types of entities and levels of interaction can also advantage many developing countries, including Muslims states providing them with a broad array of organizations with which to participate and which are founded by similar values to those discussed earlier in the chapter through the formal and informal actions like treaties, accords, resolutions, agreements, diplomatic bargaining processes, joint operations, information gathering, conferences, standards, laws and regulations (Karns, Mingst \& Stiles, 2015).

Global governance also refers to a number of problems and challenges internationally that require trans-national and non-state actor cooperation to address: terrorism and other security problems (e.g., cybersecurity), pandemics, climate change, environmental degradation, water shortage, technological advances and disruption in financial markets in globalization as well as the growing inequalities and violence that have produced large refugee migrations, human rights including the rights of women and children, the arms trade, and pandemics (Goldin, 2013; Sinclair, 2012). A related literature is that of development studies that focus on the increasing 
crisis in the developing world, more recently as the result of the 1980s economic and financial crises, the problems of debts and growth slowdowns in the 1990s, and subsequent financial crises and the negative impacts of globalization (Grugel \& Piper, 2007; Sinclair, 2012). Migration is one problem in which the Muslim world plays a significant role in Indonesia, the largest Muslim state, as a major exporter of labour, and the Muslim states of the Arabian Gulf one of the largest regions hosting foreign labour (Grugel \& Piper, 2007).

And it is also a set of 'emergent regimes, norms and rules, as well as formally constituted agencies and institutions' whose aim is to regulate global conflicts (Grugel \& Piper, 2007, p. 7) as well as a public policy practice through various networks and supra-national organisations. One example of this in the financial world is the establishment of Islamic banking which is exerting a significant influence in many regions (Sinclair, 2012). Al-Qudsy and ab Rahman (2011) define it as 'the interaction between formal institutions publicly and privately and those of civil society' (p. 613). Up to 2003, the US played hegemonic roles in global governance, however, other powers have been expanding their roles like China, India and Brazil along with IGOs outside the US orbit (Karns, Mingst \& Stiles, 2015). A non-hierarchical global governance would allow for a greater role of countries in the developing world in those core institutions of global governance include the UN, the Bretton Woods system, the General Agreement on Tariffs and Trade (GATT), the World Trade Organization (WTO), and the Organisation for Economic Cooperation and Development (OECD) and the G-8. The trend has been for a formation of other organisations like the G-77, the Non-Aligned Movement, the UN Conference on Trade and Developments (Cooper \& Alexandroff, 2010). 
In the current world order, governance of many activities has to be approached through global networks that need to include Muslim states given the many governance problems that involve Middle East countries (Slaughter, 2004), particularly since some countries in the region operate as global hubs for transportation and shipping as well as sources of conflict. A test of global governance for rising countries and regions is the degree to which they can influence key structures of the UN (like the Security Council), the Bretton Woods system, the International Monetary Fund and the World Trade Organisation reshaping them to be more democratic, representative and legitimate by increasing the participation of the developing world in the way that the G-77, Non-Aligned Movement, and UN Conference on Trade and Development have although this also increases the likelihood that consensus will not be reached (Cooper \& Alexandroff, 2010). However, to date, grounded in Islamic principles and their participation in a broad range of international governance-type organisations like the UN (UNESCO, WHO, Peacekeeping), IMF, WTO, G20 and regional or economic related organisations like OPEC, the Arab League, the GCC and environmental organisations, a number of Muslim states have already contributed to global governance.

\section{Conclusion}

While many aspects of modernization seem to be at odds with an Islamic value system such as secularisation, material development and industrialisation and technology, modernity, according to Sabet (2008), is not necessarily inimical to an Islamic worldview. On a social level, modernization is a contradictory force if defined as shedding traditional values, familial and other authority, and acquiring a fundamental individualist teleology that independently 
determines moral values. However, such a view of modernity is an ethnocentric one that not only precludes possible other paths to modernisation and judges them inferior (Najem, 2003), but also some of the social theory upon which a definition of modernity rests, in particular, a Weberian approach that conceived of other paths, and inherent in the development of modernity a set of religious values that made its development possible in the Western context (Weber, 1930). Sabet (2008) argues further that a religious perspective and traditional values can mitigate the excesses of modernisation by managing it through principles of social justice to produce a balanced synthesis.

However, if one compares the core Islamic governance and global conceptions with dominant models in the Western world, there is a high degree of compatibility. Iqbal and Lewis (2009), for example, see many characteristics that correspond to important global governance issues today: human rights, peaceful coexistence, environmental stewardship, a sharing of knowledge, scholarship, science and technology, a tradition of philanthropy, and the preserving of cultural traditions, particularly those in societies where family cohesion is important. Afsaruddin (2007) emphasises in her discussion of Islamic governance and government that the Islamic conception from the beginning adopted a broad world-view, in practice supported by a tolerance of other peoples and systems of thought and an intellectual and scientific tradition that was comprehensive of disciplines and also oriented towards absorbing knowledge from the classical period, particularly Greek philosophy and from other regions and empires as well as a deep humanism that guided their extension of protection to those of other faiths: 
Suffice it to say that [the attraction to foreign literary traditions] resulted in a much more cosmopolitan, one could even say multi-cultural, Islamic civilizational identity ... As a consequence of these intellectual and cultural trends, a specifically Islamic humanism or $a d a b$ emerge, which, according to probably the most famous belle-lettrist in Arabic literature, Amr ibn Bahr al-Jahiz ... may be defined as '(1) the total educational system of (2) a cultured Muslim who (3) took the whole world for his object of curiosity and knowledge.' (Afsarrudin, 2007, pp. 135-136)

In other words, the fundamental conception of the public good that characterises Islamic governance (Afsaruddin, 2010), was understood in an expansive way as a conception of the moral management of the world order that applied to what was understood to be global at the time. A modern Muslim view is that the highest examples of good governance in Islam demonstrate that Muslim countries can equally subscribe to human rights values and peaceful coexistence and can offer a model of inter-cultural relations for the contemporary world (Afsaruddin, 2007). From a Muslim perspective, described by Hashem (2007), the aim for global governance is for Islam to have a voice in global public life. The conceptions of Islamic good governance discussed earlier in the chapter correspond closely to those held internationally, except for a neoliberal orientation that is predicated upon an economic and highly material view, and focused on structural and functions aims. Where Islam could contribute is to the more humanistic and constructivist movements in global governance and on an individual level where imperatives of personality and character are required for the maintenance of a system of good governance as well as its proper implementation. 


\section{References}

Adamson, P. and Taylor, R. (eds) (2005). The Cambridge Companion to Arabic Philosophy. Cambridge: Cambridge University Press.

Afsaruddin, A. (2007). The First Muslims: History and Memory. Oxford: One World.

Afsaruddin, A. (2010). Where earth and heaven meet: Remembering Muhammad as head of state, in J. Brockopp (ed.) The Cambridge Companion to Muhammad (180-198). Cambridge: Cambridge University Press.

Akasoy, A. and Giglioni, G. (eds) (2013). Renaissance Averroism and Its Aftermath. Dordrecht: Springer.

Al-Buraey, M. (1985). Administrative Development: An Islamic Perspective. London: Kegan Paul.

al-Qudsy, S. \& Ab Rahman, A. (2011). Effective Governance in the Era of Caliphate Umar Ibn Al-Khattab (634-644). European Journal of Social Sciences, 18, 4, 612-624.

Al-Rodhan, N. (ed.) (2012). The Role of the Arab-Islamic World in the Rise of the West. Basingstoke: Palgrave Macmillan.

Al-Tamamy, S. (2014). Averroes, Kant and the Origins of the Enlightenment. London: I. B. Tauris.

Attar, S. (2007). The Vital Roots of European Enlightenment: Ibn Tufayl's Influence on Modern Western Thought. Lanham, MD: Lexington Books.

Baderin, M. (2000). The Evolution of Islamic Law of Nations and the Modern International Order, American Journal of Islamic Social Sciences, 17 (2), 57-80. 
Badran, M. (2001). Understanding Islam, Islamism and Islamic feminism. Journal of Women's History, 13(1), 47-52.

Barkawi, T. \& Laffey, M. (2006) The postcolonial moment in security studies, Review of International Studies, 32, 329-352.

Barnett, M. \& Duvall, R. (2005). Power in global governance, in M. Barnett and R. Duvall (eds) Power in Global Governance (1-32). Cambridge: Cambridge University Press.

Behzadi, H. (1971) The principles of legitimacy and its influence upon the Muslim political theory, Islamic Studies, 10, 4, 277-290.

Bennison, A. (2009). The Great Caliphs. New Haven: Yale University Press.

Bilgin, P. (2009). The International Political "sociology of a not so international discipline?" International Political Sociology, 3, 3, 338-342.

Black, A. (2011). The History of Islamic Political Thought. Edinburgh: Edinburgh University Press.

Boase, R. (ed.) (2010). Islam and Global Dialogue. Farnham: Ashgate.

Boroujerdi, M. (ed.) (2013). Mirror for the Muslim Prince. Syracuse, NY: Syracuse University Press.

Bowering, G. (2013). The Princeton Encyclopedia of Islamic Political Thought. Princeton, NJ: Princeton University Press.

Cline, E. (2014). 1177 B.C.: The Year Civilization Collapsed. Princeton, NJ: Princeton University Press.

Cole, J. (2009). Engaging the Muslim World. New York, NY: Palgrave Macmillan. 
Cooper, A. and Alexandroff, A. (2010). Introduction, in A. Alexandroff and A. Cooper (eds) Rising States, Rising Institutions: Challenges for Global Governance (1-16). Waterloo: Centre for International Governance Education.

Crone, P. (2004). God's Rule: Government and Islam. Edinburgh: Edinburgh University Press. Demirei, S. (2013). The Prophet Muhammad's models of coexistence and the Constitution of Medina, Versita, 4, 1, 1-10.

Edwards, I., Gadd, C. \& Hammond, N. (1971) Cambridge Ancient History. Early History of the Middle East. Cambridge: Cambridge University Press.

Fox, J. (2006). World separation of religion and state into the twenty-first century, Comparative Political Studies, 39, 537-569.

Gillani, A. and Tahir, M. (2014). The administration of Abbasids caliphate, Pakistan Journal of Commerce and Social Sciences, 8, 2, 565-571.

Gills, B. \& Thompson, W. (eds) (2006) Globalization and Global History. London: Routledge.

Goldin, I. (2013). Divided Nations. Oxford: Oxford University Press.

Grugel, J. and Piper, N. (2007). Critical Perspectives on Global Governance. London: Routledge.

Hashem, M. (2007). Islamic roots of good governance, Arab Insight, 1 (1), 63-71.

Hashmi, S. (ed.) (2002). Islamic Political Ethics. Princeton: Princeton University Press.

Hirschkind, C. (2011). What is political Islam? In F. Volpi (Ed.), Political Islam: A Critical Reader (pp. 13-15). London, UK: Routledge.

Hoffmann, M. (2005). What's global about global governance?, in A. Ba and M. Hoffmann (eds) (2005) Contending Perspectives on Global Governance (110-128). Oxford: Routledge. 
Hourani, G. (1985). Reason and Tradition in Islamic Ethics. Cambridge: Cambridge University Press.

Huntington, S. (1997). Clash of civilizations. London, UK: Simon \& Schuster.

Iqbal, Z. and Lewis, M. (2009). An Islamic Perspective on Governance. Cheltenham: Edward Elgar.

Johns, J. (2002). Arabic Administration in Norman Sicily: The Royal Dīwān. Cambridge: Cambridge University Press.

Jreisat, J. (2011). Globalism and Comparative Public Administration. Boca Raton: CRC Press.

Kamali, M. (2008). Shari'ah Law: An Introduction. Oxford: Oneworld.

Kant, I. (2006). "Toward Perpetual Peace" and Other Writings on Politics, Peace, and History. New Haven: Yale University Press.

Karns, M., Mingst, K. and Stiles, K. (2015). International Organizations: The Politics and Processes of Global Governance. Boulder, CO: Lynne Rienner.

Kennedy, H. (2005). The Caliphate. In Y. Choueiri (ed.) A Companion to the History of the Middle East (52-66). Oxford: Blackwell.

Keohane, R. (2002). Power and Governance in a Partially Globalized World. London: Routledge.

Lacoste, Y. (1984). Ibn Khaldun. London: Verso.

Mahdavi, M., \& Knight, W. (2012). Introduction. In M. Mahdavi \& W. Knight (eds) Towards the dignity of difference? Farnham, UK: Ashgate.

Maussen, M. and Bader, V. (2011). Introduction, in M. Maussen, V. Bader and A. Moors (eds) Colonial and Post-Colonial Governance of Islam (9-26). Amsterdam: Amsterdam University Press. 
Michie, J. (2011). Introduction, in J. Michie (ed.) The Handbook of Globalisation (1-13). Cheltenham: Edward Elgar.

Murphy, C. (2014). Global governance over the long haul, International Studies Quarterly, 58, 216-218.

Nader, L. (2013). Culture and dignity: Dialogues between the Middle East and the West. Chichester, UK: Wiley-Blackwell.

Najem, T. (2003). Good governance, in T. Najem and M. Hetherington (eds) Good Governance in the Middle East Oil Monarchies (1-28). London: RoutledgeCurzon.

Oliver-Dee, S. (2009). The Caliphate Question. Lanham: Rowman \& Littlefield.

Overbeek, H. (2005). Global governance, class, hegemony, in A. Ba \& M. Hoffman (eds) Contending Perspectives on Global Governance (39-56). London: Routledge.

Peters, F. (1994). A Reader on Classical Islam. Princeton: Princeton University Press.

Rosenau, J. (1990). Turbulence in World Politics. Princeton: Princeton University Press.

Rosenthal, E. (1962). Political Thought in Medieval Islam. Cambridge: Cambridge University Press.

Sabet, A. (2008). Islam and the Political. London: Pluto.

Sachedina, A. (2006). The Role of Islam in the Public Square. Isim: Amsterdam University Press.

Said, E. (1978). Orientalism. New York, NY: Vintage Books.

Shaheed, F. (1999). Constructing identities: Culture, women's agency and the Muslim world. International Social Science Journal, 51(159), 61-73.

Sharfuddin, I. (1987). Toward an Islamic administrative theory, American Journal of Islamic Social Sciences, 4 (2), 229-244. 
Sharif, M. (1963). A History of Muslim Philosophy. Vol. I. Wiesbaden: Otto Harrassowitz.

Sidani, Y. (2008). Ibn Khaldun of North Africa: an AD 1377 theory of leadership, Journal of Management History, 14, 1, 73-86.

Sinclair, T. (2012). Global governance. Cambridge: Polity.

Slaughter, A.-M. (2004). A New World Order. Princeton: Princeton University Press.

Tibi, B. (2008). Political Islam, World Politics and Europe. Abingdon: Routledge.

Volpi, F. (2011). Introduction. In F. Volpi (Ed.), Political Islam (pp. 1-7). London, UK: Routledge.

Weber, M. (1930). The Protestant Ethic and the Spirit of Capitalism. London: Unwin Hyman.

Weiss, T. (2005). Governance, good governance and global governance, in R. Wilkinson (ed.) Global Governance Reader (68-88). New York: Routledge.

Weiss, T. (2013). Global Governance. Cambridge: Polity.

Weiss, T. and Wilkinson, R. (2015). Continuity and change in global governance, in J. Gaskarth (ed.) Rising powers, global governance, and global ethics (41-56). London: Routledge.

Zein, I., al-Ahsan, A. and Zakaullah, M. (2008) Qur'anic guidance on good governance, in A. alAhsan and S. Young (eds) Guidance for Good Governance (8-22). Kuala Lumpur: International Islamic University Malaysia. 